\title{
Determinants of Childhood Mortality in South Africa: Using Categorical Data Modeling
}

\author{
KwabenaA. Kyei \\ Department of Statistics, University of Venda, Private Bag X5050, \\ Thohoyandou 0950, South Africa \\ E-mail:Kyei61@gmail.com
}

KEYWORDS Socio-economic Development. Environmental Hazards. Sensitive Index.Health-related. Anti-natal Check-ups. Maximum Likelihood Estimation

\begin{abstract}
Childhood mortality is of great interest to social scientists and policy makers concerned about the quality of life in less developed countries. Thus, the importance of the study of childhood mortality cannot be exaggerated. The levels of infant and child mortality are the two sensitive and widely used indicators of socioeconomic development. The childhood mortality rate is a refined and sensitive index of the total cultural milieu of a community or a country. It reflects among other things, the state of public health and hygiene, the environmental sanitation, cultural mores about feeding and clothing, socio-economic development, and above all, the people's attitude towards the dignity and value of human life itself. It is the simple statistical index which conveys the idea of whether environmental hazards are controlled effectively or not, in developing countries, especially in Africa. The childhood mortality situation in South Africa has been investigated in this research using South African Demographic and Health Survey II data. About ten socio-economic, demographic, environmental and healthrelated variables were analyzed using categorical data modeling (catmod) analysis. On the basis of the analysis, the study concludes that education of parents, marital status as well as the occupation of mother, the survival of the penultimate child, duration of breastfeeding, anti-natal check-ups and availability of toilets in the residence are the determinants of childhood mortality in South Africa.
\end{abstract}

\section{INTRODUCTION}

The importance of the study of childhood mortality cannot be over-emphasized because infant and child mortality levels are widely used as indicators for socio-economic development in less developed countries. The levels reflect the state of public health and hygiene, the environmental sanitation, cultural mores about feeding and clothing, socio-economic development, and above all, the people's attitude towards the dignity and value of human life itself (Bawah 2001; Akoto and Tambashe 2006). The childhood mortality level is the simple statistical index which conveys the idea of whether environmental hazards are controlled effectively or not in the developing countries.

The childhood mortality level can be used for strategic and national planning as well as a measure of socio-indicators like the quality of health care, nutrition, family planning practice and usage. The level provides evidence of policies and practices which lead to the improvement of health conditions (Cook et al. 2009). Environmental factors such as sanitation and accidents in and around the home are also reflected in the rate of childhood mortality.
In the world's poorest countries, over 30000 children under the age of five die each day from preventable causes related to conditions of extreme poverty (http//environment.about.com/ od/healthenvironment/a/child_mortality.htm). Poor nutrition, polluted drinking water, debilitating infections and accidents are some of the factors cited as causing high childhood mortality, especially in sub-Saharan Africa (Cook et al. 2009; see also www.childmortality.org). This study aims to determine the factors that affect infant, child and under-five mortality respectively in South Africa. It seeks to find out whether the factors affecting infant mortality are the same as those affecting child mortality or not and vice versa.

\section{High Childhood Mortality as a Problem to Both Society and Family}

Childhood mortality poses problems to both society and the family. High childhood mortality levels are a signal that basic health infrastructure to fight poor sanitation, environmental degradation and living condition are grossly inadequate. Additionally, they reveal that other basic facilities are absent or in a poor state, for example, 
toilet facilities, water, sewerage and the rest. Where high childhood mortality is prevalent, there is equally a display of infectious and parasitic diseases. This is an indication of poor hygienic conditions and frequent outbreaks of epidemic diseases.

In most African countries, especially among the rural people, high childhood mortality sometimes results in breakdown of marriages because many reasons are read into the "misfortune". When couples lose more than one infant (normally the first born), speculation becomes rife as to whether one of the families practice witchcraft which results in the death of the infant(s). In polygamous marriages, if one of the women should suffer this fate, all sorts of accusations are leveled against her and her parents by her rival(s). This results in an unhappy marriage, to say the least.

Frequent child loss in many African countries causes, in many cases, the couple to lose their "Christian beliefs and values" because of the attitude the society shows to them. Because such families are frowned upon and despised, they end up consulting all sorts of mediums to find out what has gone wrong with them. Consequently they no longer believe in the all-knowing God, but rather look up to other gods for solutions and/or for fortune. In most African societies, frequent infant and child deaths, and/or sterility are seen as bad omen. Parents are viewed as having been cursed for their unproven wrong deeds (Adansi-Pipim 1985). In short, childhood mortality brings sorrow, pain, despise and lack of respect to the family. It brings pain to the couple, the families and even the society at large.

\section{METHODOLOGY}

The South African Demographic and Health Survey II data covered all the ethnic groups in the country. However, since among the black population there are:

- poor socio-economic conditions;

- $\quad$ very little information on childhood mortality, and

- the little information available on childhood mortality, shows that the infant mortality is highest among this group as compared with the other ethnic groups.

This study is based on data from the black population. Mostert (no date) has said there is lack of reliable data on mortality in general and childhood mortality in particular on the black population.

Thirteen independent variables (6 variables being socio-economic indicators, 3 environmental variables, 2 demographic variables, 2 health-related variables and one nutritional variable) were investigated with the view of determining whether they affect childhood mortality (In the present study, childhood mortality is taken to mean infant, child and under-five mortality).

The variables are:

$\mathrm{X} 1=$ childhood mortality (dependent variable);

$\mathrm{X} 2=\mathrm{ANCHUP}=$ ante-natal medical check-up;

$\mathrm{X} 3=$ MEDUC $=$ education of mother;

$\mathrm{X} 4=$ MOCCUP $=$ occupation of mother;

$\mathrm{X} 5=\mathrm{MHSCH}=$ number of children born to mother;

$\mathrm{X} 6=\mathrm{M} 2 \mathrm{CH}=$ survival of penultimate child;

$\mathrm{X} 7=$ MSTAT $=$ marital status of mother;

$\mathrm{X} 8=\mathrm{TYDW}=$ type of dwelling;

$\mathrm{X} 9=$ OCCUPF $=$ occupation of husband/partner;

$\mathrm{X} 10=\mathrm{EDUCF}=$ education of husband $/$ partner;

$\mathrm{X} 11=\mathrm{WATER}=$ availability of water in residence;

$\mathrm{X} 12=$ TOILET $=$ availability of toilet in residence;

$\mathrm{X} 13=\mathrm{VACCH}=$ vaccination of children;

$\mathrm{X} 14=$ DBRFED $=$ duration of breastfeeding.

Both the chi-square test and categorical modeling analysis (catmod analysis) were applied in this study. After doing a bivariate analysis of childhood mortality and each of the 13 independent variables, four of the independent variables were eliminated because the ensuing chi-square tests showed that those variables did not have significant relationships with childhood mortality.

Ten models were constructed in the investigation of under- five mortality.

The variables in each of the models are:

- Model 1, education of the mother, marital status of the mother and the number of children born to the mother;

- Model 2, education of the mother, marital status of the mother and the survival of the penultimate child;

- Model 3, education of the mother, marital status of the mother, the number of children the mother has and occupation of the father;

- Model 4, education of the mother, marital status of the mother and occupation of the mother;

- Model 5, education of the mother, marital status of the mother, the number of children the mother has and the survival of the penultimate child; 
- Model 6, education of the mother, marital status of the mother, the number of children the mother has and the duration of the breastfeeding;

- Model 7, education of the mother, marital status of the mother, the number of children the mother has and antenatal medical check-up;

- Model 8, education of the mother, marital status of the mother, the number of children the mother has and education of the father;

- Model 9, education of the mother, marital status of the mother, the number of children the mother has and availability of a toilet in the house; and

- Model 10, education of the mother, marital status of the mother, the number of children the mother has and vaccination of the child.

The same 10 models were used in the investigations of both infant and child mortality (aged 1-4 years) separately. That is, the variables in model 1 in under- five mortality analysis are the same variables as in model 1 in infant and child mortality respectively. Similarly, the variables in model 2, 3, 4 etc. in under- five analysis are the same as those in the corresponding models in infant and child mortality analyses respectively.

Seven of the ten models were built from model 1 (stepwise), each time replacing the fourth variable in the model with a new variable. These seven models have four variables each, with three variables remaining constant. That is, the variables, education of the mother, marital status and the number of children born to the woman remain constant.

In the remaining three out of the ten models, (models 1,2 and 4) there were three variables. Two out of the three variables remain constant. They are the education of the mother and the marital status of the mother.

\section{Theoretical Importance of the Variables in the Model and the Problems Associated with the Choice and Quantification of the Variables}

There is abundance of literature supporting the fact that each of the socio-economic variables (education, occupation, income, marital status, etc.) considered here affect infant and child mortality (see Caldwell 1979, 1986; Tekce and Shorter 1984; Behm 1986; Ruzicka et al. 1989; Behm and Soto 1991). The variables are considered here in order to test whether what we know to be true in other places is equally true in South Africa or not.

The work status of a mother is an important determinant of mortality of her children at the younger ages, zero to five. The need to work, especially outside the home, may affect survival chances directly by preventing the mother from caring for the child (Tawiah 1979). This may have substantial effects through a lack of proper feeding and particularly, the lack of breastfeeding in early life. However, work outside the home is likely associated both with modernity and with higher family income, both of which will probably increase the children's chances of survival. In South Africa, a number of working women are domestic workers/maids/helpers who do not stay with their children. Unfortunately, their income/ wages are too low to compensate for their absence from home. Thus, their absence from home tends to have a negative effect on the health of their young children.

The occupation of the mother and/or her husband/partner is important, but the income received is the most important factor. The amount of money received determines how the family is able to provide for their basic needs. Because there is no information about income, the occupation of the parents, especially that of the husband/partner/father, has been taken as a proxy for the family's income. A partner who is a technician or a high school teacher or a supervisor is considered to have a better income than a sales attendant, labourer or a farm worker.

The International Labour Organisation (ILO) has over 80 different kinds of occupation. Thus occupation as a concept presents a problem because it is very difficult to define, especially in the African context. Because most black people work in the informal sector, and because they do not earn regular wages, they declare themselves as not working (unemployed or without occupation). Besides, the occupation of the current husband/partner does not necessarily refer to the partner at the time of the birth or at the death of the child (if any death has occurred). In short, the collection of information on occupation is fraught with difficulty.

Primary healthcare and health education are equally important factors affecting infant and child mortality, the longer the duration of 
breastfeeding (more than twenty months) the lower the risk of childhood mortality (Kyei 1999). The frequency of ante-natal medical check-ups increases the chances of safe delivery. It reduces the danger facing the mother or child who is suffering from anaemia, who lacks iodine, calcium or iron, because some treatment can be administered before the situation deteriorates. It is a means to 'correct' low- or under- weight problems of unborn babies as well as a means to improve the mother and the unborn baby's health. Any sickness which otherwise might have threatened the life of both the mother and child could be treated during pregnancy. The vaccination of children reduces the risk of death through measles, polio, tetanus, and other deadly diseases and epidemics.

Many studies confirm that variables like 'age of the mother', 'birth order', and 'the interval between successive births' affect infant and child mortality (see for example, Wunsch and Termote 1978; Venkatacharya 1985, 1991; Arriaga 1989; Nyarko et al. 1999). When a woman is too young (less than 17 years) or too old (older than 40 years), the risk of childhood mortality is high. Similarly, children born with an interval less than two years, have a higher risk of death than those born with an interval more than two years, controlling all other factors (Rossouw and Hofmeyr 1990). The most frequent demographic variables used besides the age of mother at birth, are: the birth order (parity) and the interval between successive births. But because these variables are not included in the questionnaire, they have been replaced by the number of children born to the mother (the family size). This choice seems to be a good substitute because a large family size, for example, would imply a short birth interval, as well as a high order of parity.

\section{Categorical Data Modeling Procedures}

The Categorical Data Modeling (catmod) is a procedure that fits linear models to functions of response frequencies and can be used for linear modeling, log-linear modeling and logistic regression. Catmod fits linear models to categorical data, facilitating such analyses as regression, analysis of variance and repeated measurement analysis. It uses maximum likelihood estimation (mle) of parameters for loglinear models and the analysis of general logits, uses weight-least squares estimation of parameters for a wide range of general linear models. The method (mle) consists of maximizing the likelihood function with respect to the parameter, $\theta$, that is the estimator. A likelihood ratio test states that the null hypothesis $H_{0}$ is rejected if and only if the ratio $\lambda$, falls in a critical region of the form $\lambda \mathrm{d}$ " $k$, where $0<k<1$,

$L(\theta)=f\left(x_{1}, x_{2}, \ldots x_{n}, \theta\right)$ is the likelihood function, and

$$
\text { the ratio defined as: } \lambda=\frac{\max L_{o}}{\max L_{1}},
$$

where $\max \mathrm{L}$ and $\max \mathrm{L}_{1}$ are the maximum values of the likelihood function for all values $\theta$ and $\omega$ respec-tively (Freund and Walpole 1987)

The catmod procedure is more flexible and more informative than other linear regression function procedures like gencat and funcat, for example, because there are numerous design features with catmod that make that possible (SAS 1985).

\section{RESULTS AND DISCUSSION}

The bivariate analysis shows that, on the basis of chi-square test, ten out of the fourteen independent variables influence the under-five mortality (see Table 1). These are the following:

- The education of the mother,

- The occupation of the mother,

- The number of children born to the mother,

- The survival of the penultimate child,

- The marital status of the mother,

- The presence of a rival to the mother,

- The occupation of the father/husband (proxy for household income)

- The education of the father,

- The duration of breastfeeding, and

- The vaccination of children against certain diseases.

While the socio-economic, demographic and health variables in the model prove to be important factors affecting under-five mortality, it is surprising to note that none of the environmental variables (the type of dwelling, water in residence, and toilet in the residence) included in the model, showed to be an important determinant of under-five mortality.

Catmod Procedure for the Analysis of Factors Affecting Under- Five Mortality

Table 2 shows that in model 1, all three variables in the model: education of the mother, marital status of the mother and the number of children that she has (children born to the mother), 
Table 1: The Chi-square test for the relationship between under-five mortality and independent variables

\begin{tabular}{llll}
\hline $\begin{array}{l}\text { Dependent } \\
\text { variables }\end{array}$ & $\begin{array}{l}\text { Mort- } \\
\text { ality }\end{array}$ & $\begin{array}{l}\text { Indepe- } \\
\text { ndent } \\
\text { varia- } \\
\text { bles }\end{array}$ & $\begin{array}{l}\text { Sam- } \\
\text { ple } \\
\text { size }\end{array}$ \\
\hline
\end{tabular}

X1 Under-five X3=MEDUC $5941 \quad 0,000$ X4=MOCCUP $6867 \quad 0,000$ $\mathrm{X} 5=\mathrm{MHSCH} \quad 7286 \quad 0,000$ $\mathrm{X} 6=\mathrm{M} 2 \mathrm{CH} \quad 7286 \quad 0,000$ X7=MSTAT $7284 \quad 0,000$ $\mathrm{X7B}=$ MHSRI $4999 \quad 0,000$ $\mathrm{X} 9=$ OCCUPF $5751 \quad 0,011$ $\mathrm{X} 10=\mathrm{EDUCF} \quad 4542 \quad 0,002$ X14=DBRFED $2039 \quad 0,002$ $\mathrm{X} 13=\mathrm{VACCH} \quad 5136 \quad 0,070$

Source: SADHS II data

have a highly significant relationship with underfive mortality. In model 2 , by replacing the variable, number of children the mother has, by the variable, the survival of the penultimate child, the latter variable now becomes the dominant determinant of the under-five mortality. The addition of this variable has "destroyed" the relationship that existed between marital status of the mother and the under-five mortality.

In model 3, the variable, occupation of the father which was added to the variables in model 1, showed no relationship with the under-five mortality. However, replacing the variable, occupation of the father by that of the mother in model 4, gives a different result. All the four variables in model 4 are important determinants of the under-five mortality.

In model 5, the variable, the survival of the penultimate child was added to the variables in model 1. The result shows that this variable has a highly significant relationship with the underfive mortality. What is more, the relationship between the variables in model 1 with the underfive mortality weakens in the presence of this additional variable. The two variables, education of the mother and the number of children the mother has, have lost the very significant relationship they had with the under-five mortality in model 1 , completely. The relationship between the marital status of the woman and the under-five mortality has become marginally significant. The overall likelihood ratio however, shows that all the four variables are strong determinants of the under-five mortality.
Table 2: Catmod analysis for the factors affecting under-five mortality

\begin{tabular}{|c|c|c|c|c|c|}
\hline Model & $\begin{array}{l}\text { Mort- } \\
\text { ality }\end{array}$ & Sources & $D F$ & $\begin{array}{l}\text { Chi- } \\
\text { square }\end{array}$ & Prob. \\
\hline \multirow[t]{5}{*}{1} & Under- & INTERCEPT & 1 & 699,31 & 0,0000 \\
\hline & & $\mathrm{X} 3=\mathrm{MEDUC}$ & 1 & 14,13 & 0,0000 \\
\hline & & X7=MSTAT & 2 & 33,41 & 0,0000 \\
\hline & & $\mathrm{X} 5=\mathrm{MHSCH}$ & 2 & 37,18 & 0,0000 \\
\hline & & L. RATIO & 11 & 19,86 & 0,0473 \\
\hline \multirow[t]{5}{*}{2} & Under- & INTERCEPT & 1 & 264,13 & 0,0000 \\
\hline & & $\mathrm{X} 3=\mathrm{MEDUC}$ & 1 & 2,84 & 0,0919 \\
\hline & & $\mathrm{X} 7=\mathrm{MSTAT}$ & 2 & 4,23 & 0,1202 \\
\hline & & $\mathrm{X} 6=\mathrm{M} 2 \mathrm{CH}$ & 1 & 55,44 & 0,0000 \\
\hline & & L. RATIO & 7 & 7,96 & 0,3365 \\
\hline \multirow[t]{6}{*}{3} & Under- & INTERCEPT & 1 & 144,91 & 0,0000 \\
\hline & five & $\mathrm{X} 3=\mathrm{MEDUC}$ & 1 & 4,26 & 0,0390 \\
\hline & & $\mathrm{X} 7=\mathrm{MSTAT}$ & 2 & 30,38 & 0,0000 \\
\hline & & X9=OCCUPF & 4 & 4,96 & 0,2919 \\
\hline & & $\mathrm{X} 5=\mathrm{MHSCH}$ & 2 & 29,33 & 0,0000 \\
\hline & & L. RATIO & 51 & 57,57 & 0,2452 \\
\hline \multirow[t]{5}{*}{4} & Under- & INTERCEPT & 1 & 967,97 & 0,0000 \\
\hline & five & $\mathrm{X} 3=\mathrm{MEDUC}$ & 1 & 29,57 & 0,0000 \\
\hline & & $\mathrm{X} 7=\mathrm{MSTAT}$ & 2 & 20,04 & 0,0000 \\
\hline & & $\mathrm{X} 4=\mathrm{MOCCUP}$ & 3 & 6,89 & 0,0755 \\
\hline & & L. RATIO & 17 & 40,23 & 0,0012 \\
\hline \multirow[t]{6}{*}{5} & Under- & INTERCEPT & 1 & 114,41 & 0,0000 \\
\hline & five & X3=MEDUC & 1 & 2,37 & 0,1237 \\
\hline & & $\mathrm{X} 5=\mathrm{MHSCH}$ & 2 & 0,86 & 0,6511 \\
\hline & & $\mathrm{X} 6=\mathrm{M} 2 \mathrm{CH}$ & 1 & 55,33 & 0,0000 \\
\hline & & X7=MSAT & 2 & 4,74 & 0,0933 \\
\hline & & L. RATIO & $5 \overline{7}$ & 37,46 & 0,0211 \\
\hline \multirow[t]{6}{*}{6} & Under- & INTERCEPT & 1 & 134,62 & 0,0000 \\
\hline & five & $\mathrm{X} 3=\mathrm{MEDUC}$ & 1 & 2,83 & 0,0925 \\
\hline & & $\mathrm{X} 7=$ MSTAT & 2 & 6,97 & 0,0306 \\
\hline & & $\mathrm{X} 5=\mathrm{MHSCH}$ & 2 & 3,08 & 0,2140 \\
\hline & & $\mathrm{X} 14=\mathrm{DBRFED}$ & 4 & 19,49 & 0,0006 \\
\hline & & L. RATIO & 57 & 46,37 & 0,0417 \\
\hline \multirow[t]{6}{*}{7} & Under- & INTERCEPT & 1 & 230,58 & 0,0000 \\
\hline & & $\mathrm{X} 3=\mathrm{MEDUC}$ & 1 & 6,48 & 0,0109 \\
\hline & & X7=MSTAT & 2 & 8,95 & 0,0114 \\
\hline & & $\mathrm{X} 5=\mathrm{MHSCH}$ & 2 & 2,65 & 0,2652 \\
\hline & & $\mathrm{X} 2=\mathrm{ANCHUP}$ & 3 & 4,19 & 0,2419 \\
\hline & & L. RATIO & 45 & 39,03 & 0,7219 \\
\hline \multirow[t]{6}{*}{8} & Under- & INTERCEPT & 1 & 36,52 & 0,0000 \\
\hline & five & $\mathrm{X} 3=\mathrm{MEDUC}$ & 1 & 2,97 & 0,0847 \\
\hline & & $\mathrm{X} 5=\mathrm{MHSCH}$ & 2 & 19,52 & 0,0001 \\
\hline & & $\mathrm{X} 10=\mathrm{EDUCF}$ & 2 & 2,65 & 0,2658 \\
\hline & & $\mathrm{X} 7=\mathrm{MSTAT}$ & 2 & 26,84 & 0,0000 \\
\hline & & L. RATIO & 31 & 43,91 & 0,0622 \\
\hline \multirow[t]{6}{*}{9} & Under- & INTERCEPT & 1 & 336,08 & 0,0000 \\
\hline & five & $\mathrm{X} 3=\mathrm{MEDUC}$ & 1 & 10,11 & 0,0015 \\
\hline & & $\mathrm{X} 5=\mathrm{MHSCH}$ & 2 & 22,19 & 0,0000 \\
\hline & & $\mathrm{X} 12=\mathrm{TOILET}$ & 1 & 1,98 & 0,1596 \\
\hline & & $\mathrm{X} 7=\mathrm{MSTAT}$ & 2 & 28,74 & 0,0000 \\
\hline & & L. RATIO & 25 & 33,36 & 0,1223 \\
\hline \multirow[t]{6}{*}{10} & Under- & INTERCEPT & 1 & 308,78 & 0,0000 \\
\hline & five & $\mathrm{X} 3=\mathrm{MEDUC}$ & 1 & 12,96 & 0,0003 \\
\hline & & $\mathrm{X} 5=\mathrm{MHSCH}$ & 2 & 63,11 & 0,0000 \\
\hline & & $\mathrm{X} 7=\mathrm{MSTAT}$ & 2 & 7,71 & 0,0212 \\
\hline & & $\mathrm{X} 13=\mathrm{VACCH}$ & 2 & 4,26 & 0,1188 \\
\hline & & L. RATIO & 35 & 38,66 & 0,3077 \\
\hline
\end{tabular}

Source: SADHS II data 
Similarly, in model 6, the addition of the variable, duration of breastfeeding to the three variables in model 1 , weakens the relationship between under -five mortality on the one hand, and education of the mother and the marital status of the mother, on the other. The significant relationship between the number of children born to the mother (the number of children the mother has) and under- five mortality disappears completely. However, the relationship between marital status of the mother and education of the mother, on the one hand, and the under- five mortality, on the other hand, remains significant. Particularly, the relationship between marital status and under- five mortality remains significant. The results further show that the fourth variable, duration of breastfeeding, has a very strong relationship with the under- five mortality.

In model 7, when the variable, ante-natal medical check-up was added to the variables in model 1 , the highly significant relationship that the variables in mode 1 had with the under-five mortality weakened. The number of children the woman has, lost its significant relationship. The added variable, ante-natal medical check-up, itself did not show to be a determinant of the under- five mortality.

In model 8 , the variable, education of the father, per se, did not show any significant relationship with the under-five mortality. Similarly, in model 9 , the variable, availability of a toilet in the residence, did not appear to have a significant relationship with the under-five mortality. Equally in model 10, the variable, vaccination of children, did not seem to have a relationship with the under-five mortality.

From the ten models, it was clear that the following variables: occupation of the father, ante-natal medical check-up, availability of a toilet in the residence and vaccination of children did not have significant relationship with under-five mortality. The other six have proved to be factors affecting the under-five mortality. The occupation of the mother is seen to be a weak determinant in the presence of education of mother and her marital status. Education of the father becomes a determinant in the presence of other variables like the number children the woman has, her education, and her marital status.

In model 2, once a woman has lost a child previously, her marital status becomes irrelevant in determining the under-five mortality. It equally renders the number of children the woman has and her education unimportant factors (see model 5).

In short, the following variables are determinants of under- five mortality:

- Education of the mother,

- Marital status of the mother,

- The number of children the mother has,

- Duration of breastfeeding,

- The survival of the penultimate child; and

- Occupation of the mother.

The first five are strong determinants, while occupation of mother is a weak one.

Once a previous loss of a child has occurred in a family the other factors do not play any important role in determining the under-five mortality. It can therefore be underlined that the survival of the penultimate child is a dominant factor among all the determinants of the underfive mortality, as far as this study is concerned.

\section{Catmod Procedure for the Analysis of Factors Affecting Infant Mortality}

The same procedures were also followed to determine the factors affecting infant mortality. The variables that had significant relationships with infant mortality during the chi-square tests were taken. They were then tested using catmod procedure. All ten models were repeated in the same manner and the results obtained are summarized in Table 3.

The factors that strongly affect infant mortality are mostly the same as those that affected under-five mortality (see Table 3 ). The strongest ones are:

- Education of the mother,

- Marital status of the mother,

- Number of children the mother has, and

- Survival of the penultimate child.

The duration of breastfeeding as well as antenatal medical check-ups also influence infant mortality but not very strongly.

It is clear that the factors affecting infant mortality are not strictly the same as the factors affecting the under-five mortality. For example, while occupation of the mother was considered an important factor affecting under-five, it does not affect infant mortality.

Conversely, ante-natal medical check-up affects infant mortality but does not affect the under-five mortality at all. 
Table 3: Catmod analysis for the factors affecting infant mortality

\begin{tabular}{|c|c|c|c|c|c|}
\hline Model & $\begin{array}{l}\text { Mort- } \\
\text { ality }\end{array}$ & Sources & $D F$ & $\begin{array}{l}\text { Chi- } \\
\text { square }\end{array}$ & Prob. \\
\hline \multirow[t]{5}{*}{1} & \multirow[t]{5}{*}{ Infant } & INTERCEPT & 1 & 565,26 & 0,0000 \\
\hline & & X3=MEDUC & 1 & 9,05 & 0,0026 \\
\hline & & X7=MSTAT & 2 & 15,48 & 0,0004 \\
\hline & & $\mathrm{X} 5=\mathrm{MHSCH}$ & 2 & 9,35 & 0,0093 \\
\hline & & L. RATIO & 11 & 20,44 & 0,0397 \\
\hline \multirow[t]{5}{*}{2} & \multirow{5}{*}{ Infant } & INTERCEPT & 1 & 149,09 & 0,0000 \\
\hline & & X3=MEDUC & 1 & 1,53 & 0,2157 \\
\hline & & X7=MSTAT & 2 & 1,34 & 0,5127 \\
\hline & & $\mathrm{X} 6=\mathrm{M} 2 \mathrm{CH}$ & 1 & 29,19 & 0,000 \\
\hline & & L. RATIO & 7 & 7,28 & 0,4002 \\
\hline \multirow[t]{6}{*}{3} & \multirow[t]{6}{*}{ Infant } & INTERCEPT & 1 & 172,26 & 0,0000 \\
\hline & & $\mathrm{X} 3=\mathrm{MEDUC}$ & 1 & 1,40 & 0,2369 \\
\hline & & $\mathrm{X} 7=\mathrm{MSTAT}$ & 2 & 16,82 & 0,0002 \\
\hline & & $\mathrm{X} 9=\mathrm{OCCUPF}$ & 4 & 4,85 & 0,3034 \\
\hline & & $\mathrm{X} 5=\mathrm{MHSCH}$ & 2 & 5,27 & 0,0719 \\
\hline & & L. RATIO & 51 & 47,56 & 0,6110 \\
\hline \multirow[t]{5}{*}{4} & \multirow{5}{*}{ Infant } & INTERCEPT & 1 & 507,09 & 0,0000 \\
\hline & & X3=MEDUC & 1 & 5,08 & 0,0242 \\
\hline & & X7=MSTAT & 2 & 16,10 & 0,0003 \\
\hline & & $\mathrm{X} 4=$ MOCCUP & 3 & 4,50 & 0,2122 \\
\hline & & L. RATIO & 17 & 22,33 & 0,1724 \\
\hline \multirow[t]{6}{*}{5} & \multirow{6}{*}{ Infant } & INTERCEPT & 1 & 107,67 & 0,0000 \\
\hline & & X3=MEDUC & 1 & 1,65 & 0,1985 \\
\hline & & $\mathrm{X} 5=\mathrm{MHSCH}$ & 2 & 0,16 & 0,9211 \\
\hline & & $\mathrm{X} 6=\mathrm{M} 2 \mathrm{CH}$ & 1 & 29,21 & 0,0000 \\
\hline & & $\mathrm{X} 7=\mathrm{MSAT}$ & 2 & 1,04 & 0,5943 \\
\hline & & L. RATIO & 57 & 26,58 & 0,2276 \\
\hline \multirow[t]{6}{*}{6} & \multirow{6}{*}{ Infant } & INTERCEPT & 1 & 116,10 & 0,0000 \\
\hline & & $\mathrm{X} 3=\mathrm{MEDUC}$ & 1 & 2,64 & 0,1045 \\
\hline & & $\mathrm{X} 7=$ MSTAT & 2 & 1,76 & 0,4151 \\
\hline & & $\mathrm{X} 5=\mathrm{MHSCH}$ & 2 & 0,07 & 0,9643 \\
\hline & & $\mathrm{X} 14=\mathrm{DBRFED}$ & 4 & 8,55 & 0,0735 \\
\hline & & L. RATIO & 57 & 40,10 & 0,9563 \\
\hline \multirow[t]{6}{*}{7} & \multirow[t]{6}{*}{ Infant } & INTERCEPT & 1 & 167,29 & 0,0000 \\
\hline & & X3=MEDUC & 1 & 3,04 & 0,0813 \\
\hline & & X7=MSTAT & 2 & 8,60 & 0,0136 \\
\hline & & $\mathrm{X} 5=\mathrm{MHSCH}$ & 2 & 1,11 & 0,5741 \\
\hline & & $\mathrm{X} 2=\mathrm{ANCHUP}$ & 3 & 7,23 & 0,0650 \\
\hline & & L. RATIO & 45 & 48,66 & 0,3281 \\
\hline \multirow[t]{6}{*}{8} & \multirow[t]{6}{*}{ Infant } & INTERCEPT & 1 & 52,55 & 0,0000 \\
\hline & & $\mathrm{X} 3=\mathrm{MEDUC}$ & 1 & 1,71 & 0,1905 \\
\hline & & $\mathrm{X} 5=\mathrm{MHSCH}$ & 2 & 3,36 & 0,1860 \\
\hline & & $\mathrm{X} 10=\mathrm{EDUCF}$ & 2 & 0,17 & 0,9185 \\
\hline & & $\mathrm{X} 7=$ MSTAT & 2 & 10,69 & 0,0048 \\
\hline & & L. RATIO & 31 & 38,91 & 0,1278 \\
\hline \multirow[t]{6}{*}{9} & Infant & INTERCEPT & 1 & 269,43 & 0,0000 \\
\hline & & $\mathrm{X} 3=\mathrm{MEDUC}$ & 1 & 5,24 & 0,0221 \\
\hline & & $\mathrm{X} 5=\mathrm{MHSCH}$ & 2 & 4,53 & 0,1038 \\
\hline & & $\mathrm{X} 12=\mathrm{TOILET}$ & 1 & 1,17 & 0,2793 \\
\hline & & $\mathrm{X} 7=\mathrm{MSTAT}$ & 2 & 10,16 & 0,0062 \\
\hline & & L. RATIO & 25 & 26,86 & 0,3628 \\
\hline 10 & Infant & INTERCEPT & 1 & 192,68 & 0,0000 \\
\hline & & $\mathrm{X} 3=\mathrm{MEDUC}$ & 1 & 4,27 & 0,0388 \\
\hline & & $\mathrm{X} 5=\mathrm{MHSCH}$ & 2 & 1,29 & 0,5248 \\
\hline & & $\mathrm{X} 7=$ MSTAT & 2 & 9,07 & 0,0107 \\
\hline & & $\mathrm{X} 13=\mathrm{VACCH}$ & 2 & 1,11 & 0,5753 \\
\hline & & L. RATIO & 35 & 33,58 & 0,5365 \\
\hline
\end{tabular}

Source: SADHS II data
Catmod Procedure for the Analysis of Factors Affecting Child Mortality (Aged 1 - 5 Years)

Again, the same procedures used for the under-five and infant mortalities were also used to determine the factors affecting child mortality. The results obtained are summarized in the Table 4.

In most cases, the results here are similar to those obtained in the under-five and/ or infant mortality analyses. The factors that strongly affect child mortality are:

- Education of the mother,

- Marital status of the mother,

- Number of children the mother has,

- Survival of the penultimate child,

- Vaccination of children

- Duration of breastfeeding, and

- Availability of toilet in residence.

The factors affecting child mortality also differ slightly from those that affect under-five mortality and infant mortality. For the under-five mortality, the variable, vaccination of children was not one of the determinants, but in child mortality, it is. On the other hand, while the variable, vaccination of children, strongly affects child mortality, the variable, ante-natal medical check-ups, is the one that rather affects infant mortality.

Availability of a toilet in the residence reduces the risk of child mortality, but it does not affect the under-five mortality nor the infant mortality.

In short, we see that attendance at hospitals/ clinics for ante-natal medical check-ups is a more important determinant of infant mortality than occupation of the mother. When a woman goes for a medical consultation during pregnancy, the risk of infant mortality is reduced by about 40 percent (see Table 5). On the other hand, the longer the duration of breastfeeding (from HIVnegative women) the lower the risk of child mortality; risk reduced by over 33 percent (see Table 5). Another important factor for the survival of children is vaccination of children. A child who is vaccinated has about one and half times better chances of surviving than a child who has not been vaccinated.

The survival of children is a very important determinant of childhood mortality. The mortality rate is more than doubled when a family has already lost a child (see Table 5).

Married women's children have about 20 percent lower childhood mortality than the 
Table 4: Catmod analysis for the factors affecting child mortality

\begin{tabular}{|c|c|c|c|c|c|}
\hline Model & $\begin{array}{l}\text { Mort- } \\
\text { ality }\end{array}$ & Sources & $D F$ & $\begin{array}{l}\text { Chi- } \\
\text { square }\end{array}$ & Prob. \\
\hline \multirow[t]{5}{*}{1} & \multirow[t]{5}{*}{ Child } & INTERCEPT & 1 & 573,54 & 0,0000 \\
\hline & & X3=MEDUC & 1 & 10,86 & 0,0010 \\
\hline & & X7=MSTAT & 2 & 18,10 & 0,0001 \\
\hline & & $\mathrm{X} 5=\mathrm{MHSCH}$ & 2 & 78,23 & 0,0000 \\
\hline & & L. RATIO & 11 & 25,82 & 0,0069 \\
\hline \multirow[t]{5}{*}{2} & \multirow[t]{5}{*}{ Child } & INTERCEPT & 1 & 137,43 & 0,0000 \\
\hline & & X3=MEDUC & 1 & 0,74 & 0,3893 \\
\hline & & X7=MSTAT & 2 & 2,85 & 0,2411 \\
\hline & & $\mathrm{X} 6=\mathrm{M} 2 \mathrm{CH}$ & 1 & 71,94 & 0,0000 \\
\hline & & L. RATIO & 7 & 6,77 & 0,4529 \\
\hline \multirow[t]{6}{*}{3} & \multirow{6}{*}{ Child } & INTERCEPT & 1 & 113,55 & 0,0000 \\
\hline & & $\mathrm{X} 3=\mathrm{MEDUC}$ & 1 & 3,24 & 0,0717 \\
\hline & & X7=MSTAT & 2 & 16,03 & 0,0003 \\
\hline & & X9=OCCUPF & 4 & 6,81 & 0,1463 \\
\hline & & $\mathrm{X} 5=\mathrm{MHSCH}$ & 2 & 60,54 & 0,0000 \\
\hline & & L. RATIO & 51 & 58,90 & 0,2089 \\
\hline \multirow[t]{5}{*}{4} & \multirow{5}{*}{ Child } & INTERCEPT & 1 & 631,24 & 0,0000 \\
\hline & & $\mathrm{X} 3=\mathrm{MEDUC}$ & 1 & 13,39 & 0,0003 \\
\hline & & X7=MSTAT & 2 & 16,58 & 0,0003 \\
\hline & & $\mathrm{X} 4=\mathrm{MOCCUP}$ & 3 & 5,00 & 0,1720 \\
\hline & & L. RATIO & 17 & 26,06 & 0,0734 \\
\hline \multirow[t]{6}{*}{5} & \multirow{6}{*}{ Child } & INTERCEPT & 1 & 91,16 & 0,0000 \\
\hline & & X3=MEDUC & 1 & 0,33 & 0,5577 \\
\hline & & $\mathrm{X} 5=\mathrm{MHSCH}$ & 2 & 4,60 & 0,1004 \\
\hline & & $\mathrm{X} 6=\mathrm{M} 2 \mathrm{CH}$ & 1 & 70,63 & 0,0000 \\
\hline & & $\mathrm{X} 7=\mathrm{MSAT}$ & 2 & 3,86 & 0,1449 \\
\hline & & L. RATIO & 57 & 37,55 & 0,0206 \\
\hline \multirow[t]{6}{*}{6} & \multirow[t]{6}{*}{ Child } & INTERCEPT & 1 & 112,98 & 0,0000 \\
\hline & & $\mathrm{X} 3=\mathrm{MEDUC}$ & 1 & 1,21 & 0,2717 \\
\hline & & $\mathrm{X} 7=\mathrm{MSTAT}$ & 2 & 7,72 & 0,0211 \\
\hline & & $\mathrm{X} 5=\mathrm{MHSCH}$ & 2 & 6,87 & 0,0322 \\
\hline & & X14=DBRFED & 4 & 23,83 & 0,0001 \\
\hline & & L. RATIO & 57 & 54,96 & 0,5521 \\
\hline \multirow[t]{6}{*}{7} & \multirow[t]{6}{*}{ Child } & INTERCEPT & 1 & 201,04 & 0,0000 \\
\hline & & $\mathrm{X} 3=\mathrm{MEDUC}$ & 1 & 6,75 & 0,0094 \\
\hline & & $\mathrm{X} 7=\mathrm{MSTAT}$ & 2 & 7,79 & 0,0203 \\
\hline & & $\mathrm{X} 5=\mathrm{MHSCH}$ & 2 & 8,63 & 0,0133 \\
\hline & & $\mathrm{X} 2=\mathrm{ANCHUP}$ & 3 & 4,84 & 0,1840 \\
\hline & & L. RATIO & 45 & 39,85 & 0,6500 \\
\hline \multirow[t]{6}{*}{8} & \multirow[t]{6}{*}{ Child } & INTERCEPT & 1 & 32,56 & 0,0000 \\
\hline & & $\mathrm{X} 3=\mathrm{MEDUC}$ & 1 & 2,38 & 0,1227 \\
\hline & & $\mathrm{X} 5=\mathrm{MHSCH}$ & 2 & 52,15 & 0,0000 \\
\hline & & $\mathrm{X} 10=\mathrm{EDUCF}$ & 2 & 3,26 & 0,1959 \\
\hline & & $\mathrm{X} 7=$ MSTAT & 2 & 16,30 & 0,0003 \\
\hline & & L. RATIO & 31 & 39,75 & 0,1349 \\
\hline \multirow[t]{6}{*}{9} & Child & INTERCEPT & 1 & 278,44 & 0,0000 \\
\hline & & $\mathrm{X} 3=\mathrm{MEDUC}$ & 1 & 9,38 & 0,0022 \\
\hline & & $\mathrm{X} 5=\mathrm{MHSCH}$ & 2 & 56,98 & 0,0000 \\
\hline & & $\mathrm{X} 12=\mathrm{TOILET}$ & 1 & 0,69 & 0,4053 \\
\hline & & $\mathrm{X} 7=\mathrm{MSTAT}$ & 2 & 16,88 & 0,0002 \\
\hline & & L. RATIO & 25 & 46,08 & 0,0043 \\
\hline 10 & Child & INTERCEPT & 1 & 196,88 & 0,0000 \\
\hline & & $\mathrm{X} 3=\mathrm{MEDUC}$ & 1 & 6,75 & 0,0094 \\
\hline & & $\mathrm{X} 5=\mathrm{MHSCH}$ & 2 & 8,62 & 0,0134 \\
\hline & & $\mathrm{X} 7=$ MSTAT & 2 & 8,08 & 0,0176 \\
\hline & & $\mathrm{X} 13=\mathrm{VACCH}$ & 2 & 9,43 & 0,0090 \\
\hline & & L. RATIO & 35 & 35,89 & 0,3797 \\
\hline
\end{tabular}

Source: SADHS II data
Table 5: Variation of under-five mortality, for example, with changes in a given variable when all other variables remain constant

\begin{tabular}{|c|c|c|c|}
\hline Variables & Category & $\begin{array}{l}\text { Prob. } \\
\text { of } \\
\text { living }\end{array}$ & $\begin{array}{l}\text { Prob. } \\
\text { of } \\
\text { dying }\end{array}$ \\
\hline $\mathrm{X} 3=$ & Lower education, $<$ std 7 & 0,87 & 0,13 \\
\hline MEDUC & Higher education, $>$ std 7 & 0,93 & 0,07 \\
\hline \multirow[t]{3}{*}{$\mathrm{X} 7=\mathrm{MSTAT}$} & Never Married & 0,90 & 0,10 \\
\hline & "Separated" & 0,88 & 0,12 \\
\hline & Married & 0,92 & 0,08 \\
\hline \multirow[t]{3}{*}{$\mathrm{X} 5=\mathrm{MHSCH}$} & I 1-3 children & 0,94 & 0,06 \\
\hline & 4-6 children & 0,91 & 0,09 \\
\hline & More than 6 children. & 0,81 & 0,19 \\
\hline \multirow[t]{2}{*}{$\mathrm{X} 6=\mathrm{M} 2 \mathrm{CH}$} & No loss of a child & 0,95 & 0,05 \\
\hline & Loss of a child & 0,89 & 0,11 \\
\hline $\mathrm{X} 14=$ & $<12$ months & 0,90 & 0,10 \\
\hline \multirow[t]{3}{*}{ DBRFD } & Exactly 12 months & 0,92 & 0,08 \\
\hline & $13-23$ months & 0,93 & 0,07 \\
\hline & 24 or more months & 0,94 & 0,06 \\
\hline $\mathrm{X} 2=$ & Saw a doctor & 0,85 & 0,15 \\
\hline \multirow[t]{2}{*}{ ANCHUP } & Saw a nurse & 0,82 & 0,18 \\
\hline & Saw nobody & 0,73 & 0,27 \\
\hline $\mathrm{X} 13=$ & Child vaccinated & 0,88 & 0,12 \\
\hline VACCN & Child not vaccinated & 0,82 & 0,18 \\
\hline
\end{tabular}

Source: SADHS II data

children of "separated" women (that is, divorced, widowed and/or separated). The children of married women have about 10 per cent lower childhood mortality rate than those of single women. Married women without rivals have a lower risk of childhood mortality.

Female formal education, especially up to the completion of grade ten, has been noted as an important determinant (Caldwell 1979, 1986; Tekce and Shorter 1984; Ruzickaet al. 1989). It has been confirmed in this study that women's education after nine-successful-years of schooling (after standard seven) is a necessary and essential factor to promote a decline in childhood mortality. The need to encourage female higher education cannot be over emphasized. There is equally a need to train the adult to be more environmentally conscious. Reports of epidemics in South African townships are common. Attempts should be made to redress the problem of poor sanitation and dangerous environmental situations.

Not all diseases can be treated or prevented in hospitals. Diarrhoea, measles and cholera are best prevented by basic hygiene. Clean water, washing of hands before eating, washing of hands after visiting toilets, and drinking boiled water in certain cases are a few of the ways to fight these deadly diseases. 
Many African traditions make the married woman subservient to her husband. Some educated women, including graduates with higher degrees from universities, in Africa, still find themselves enslaved by their husbands/ traditions, particularly when the question of sex and procreation is discussed (Adewuyi 1999; Kritz 1999). Even though most African women desire smaller families, the actual family size is bigger (Zaky 1999). Unless review of the existing traditional practices takes place, as well as the culture turned around, formal education alone will not be able to achieve the family size, and for that matter, the childhood mortality level that is desired.

\section{CONCLUSION}

Even though South African has had an African government for the past sixteen years, a high proportion of the African people do not have homes. They live in shacks in shanty and places where they battle with social and economic problems, including malnutrition and diseases. Some children lack parental care and good food. Some of the unemployed parents do not have financial means to care for the children. Some children are even abandoned in the streets to fend for themselves. This pathetic scene needs proper investigation, strategies and actions to correct and improve the quality of the children's lives.

The results in this study show that the factors affecting child mortality are not necessarily the same as those affecting infant mortality. Therefore measures that would have to be taken to control infant mortality might not necessary be the same for controlling child mortality.

\section{RECOMMENDATIONS}

Based on the results of the analyses done here, this study wants to recommend the following:

- Pregnant women should be advised to go to hospital or clinics to consult doctors or professional midwives in order to know the health status of themselves and their unborn babies. This will increase the chances of survival of their unborn babies.

- Young females attending schools should be encouraged and supported to complete at least nine successful years of schooling (complete high school education) in order to empower themselves so that they can confidently take care of their children properly when they get married in the future.

- Breastfeeding mothers, especially those working at home, should know and practice longer period of breastfeeding, because breastfeeding their babies for more than 24 months increases the survival of their children by at least 33 percent.

- Health budgets in all African countries are quite small compared with budgets for other areas. It is especially important for health programmes to be directed at those areas where they are needed most, and most apt to have a significant impact on mortality, especially on childhood mortality.

\section{REFERENCES}

Adansi-Pipim G 1985. Levels, trends and determinants of infant and child mortality. In: S Singh, JY Owusu, IH Shah (Eds.): Demographic Patterns in Ghana: Evidence from Ghana Fertility Survey 1979-1980. The Hague: International Statistical Institute (ISI) pp. $193-226$.

Adewuyi AA 1999. Power and privilege: The male issue in fertility transition in sub-Saharan African. The African Population in the $21^{\text {st }}$ Century. Dakar: Union of African Population Studies (UAPS), 2: 2-14.

Akoto E, Tambashe BO 2006. Socio-economic Inequalities in Infant and Child Mortality among Urban and Rural Areas in Sub-Saharan Africa. From< http:/ /www.demogr.pmg.de/papers/workshop 020619> (Retrieved March 6-7, 2011)

Arriaga EE 1989. Changing trends in mortality decline during the last decades. In: L Ruzicka, G Wunsch, P Kane (Eds.): Differential Mortality: Methodological Issues and Biosocial Factors. Oxford: Claredon Press, pp.105-130.

Bawa AA 2001.Living Standards, Household Size and Childhood Survival in Africa: Evidence from Census Data. University of Pennsylvania, Population Studies Center, Philadelphia. From< http: www. iussp.org/Brazil/2001> (Retrieved March 10, 2011).

Behm H 1986. Final Report on the Research Project on Infant and Childhood Mortality in the Third World. CICRED, Inter-centre Co-operative Research Programme. Geneva: WHO. 1- 36.

Behm H , Soto AR 1991. Socio-economic Differentials in Child Mortality: Case Study, Costa Rica. Child Mortality in Developing Countries: Socio-economic Differentials, Trends and Implications. New York: United Nations, 38-52.

Caldwell JC 1979. Education as a factor in mortality decline: An examination of Nigerian data. Population Studies, 33 (4): 395-413.

Caldwell JC 1986. Route to low mortality in poor countries. Population and Development Review, 12 (2): 171-200. 
Cook HJ, Bhattacharya S, Hardy A (Eds.) 2009. History of the Social Determinants of Health: Global Histories, Contemporary Debates. Orient Blackswan. From<http:www.easternbookcorporation.com.> (Retrieved March 9, 2011).

Freund JE, Walpole RE 1987. Mathematical Statistics. London: Prince-Hall, Inc. From http//environment. about.From $<\mathrm{com} / \mathrm{od} / \mathrm{healthenvironment/a/child}$ mortality. htm.> (Retrieved November 30, 2011).

Kritz MM 1999. Husband and wife agreement, contraceptive use and ethnicity in Nigeria. The African Population in the $21^{s t}$ Century. Dakar: Union of African Population Studies (UAPS), 2: 15-38 .

Kyei KA 1999. The mode of feeding that promotes higher survival among children. The African Population in the $21^{\text {st }}$ Century. Dakar: Union of African Population Studies (UAPS), 1: 193-212.

Nyarko P, Madise N, Diamond I 1999. Infant Mortality and pace of childbearing in Ghana. Some evidence of some preference. The African Population in the $21^{\text {st }}$ Century. Dakar: Union of African Population Studies (UAPS), (3) 617-644.

Mostert WP (no date). DHS1 Methodology. A HandOut Describing the South African Demographic and Health Survey. Pretoria: HSRC.

Rossouw JPH, Hofmeyr B 1990. Infant and child mortality in South Africa: Levels, differentials and determinants. In: WP Mostert, JM Lotter (Eds.): South Africa's Demographic Future. Pretoria: HSRC, pp.33-44.

Ruzicka L, Wunsch G, Kane P (Eds.) 1989. Differential Mortality: Methodological Issues and Biosocial Factors. Oxford: Claredon Press.
SAS 1985. User's Guide: Statistics. $5^{\text {th }}$ Edition. Cary: SAS Institute.

Tawiah EO 1979. Some Demographic and Social Differentials in Infant and Early Childhood Mortality in Ghana. Population Dynamics, Fertility and Childhood Mortality in Africa. Proceedings of the Experts Group Meeting on Fertility and Mortality Levels and Trends in Africa and Their Implications, UNECA, Monrovia, Liberia, November 26 December 1.

Tecke B, Shorter C 1984. Determinants of child mortality: A study of squatter settlements in Jordan. Population and Development, Supplement to 10: 257-280.

Venkatacharya K 1985. An approach to the Study of Socio-biological Determinants of Infant and Child Morbidity and Mortality. Paper Delivered at an International Population Conference, Florence 1985, June 5 - 12, Vol. 2, Liege, Belgium, IUSSP, $237-253$.

Venkatacharya K 1991. Socio-economic Differentials in Child Mortality: Case Study, Kenya. Child Mortality in Developing Countries: Socio-economic Differentials, Trends and Implications. New York: United Nations, pp. 29-37.

Wunsch G, Termote M 1978. Introduction to Demographic Analyses: Principles and Methods. London: Plenum Press. From <www. childmoratlity. org/ (Retrieved November 18, 2011).

Zaky HHM 1999. Husband-Wife inconsistencies in fertility preferences in Egypt. The African Population in the $21^{\text {st }}$ Century. Dakar: Union of African Population Studies (UAPS), 2: 117-134. 